\title{
PAJAK PENGHASILAN TERHADAP TENAGA KERJA ASING SEBAGAI SUBYEK HUKUM PAJAK
}

\author{
Hendy Ramadhan \\ hendyramadhan@yahoo.com \\ Universitas Airlangga
}

\begin{abstract}
Foreign workers who work in Indonesia, have rights and obligations that are governed by the laws and regulations applicable in Indonesia, including rules relating to taxation. The foreign workers residing in Indonesia may be subject to tax laws in Indonesia. For the implementatio of legal order in the field of taxation, there is a need to apply the law of income tax on foreign workers who work in Indonesia. This paper discusses the legal basis for the imposition of foreign workers income tax in Indonesia as well as the form of liability for violations of income tax regulation on foreign workers in Indonesia. Based on this paper, foreign worker is one of the subject of income tax in Indonesia and can be subject to domestic tax or foreign tax subject depending on how long they have worked in Indonesia. Whereas in the event of any fraud related to the income tax on foreign worker, in the case the tax deduction is done by the company where the foreign worker is working, then the sanction given to the party who withholds the income tax
\end{abstract}

Keywords: Foreign Labor; Income Taxation; Law Subject.

\begin{abstract}
Abstrak
Tenaga kerja asing yang bekerja di Indonesia memiliki hak dan kewajiban yang diatur oleh peraturan perundang-undangan yang berlaku di Indonesia, termasuk aturan yang berkaitan dengan perpajakan. Tenaga kerja asing yang berada di Indonesia dapat menjadi subyek hukum pajak di Indonesia, sehingga hak dan kewajibannya dibidang perpajakan berlaku. Demi terciptanya ketertiban hukum dibidang perpajakan perlu adanya upaya penerapan hukum pajak penghasilan terhadap tenaga kerja asing yang bekerja di Indonesia. Tulisan ini membahas mengenai dasar hukum pengenaan pajak penghasilan tenaga kerja asing di Indonesia serta bentuk pertanggung jawaban bagi pelanggar pengaturan pajak penghasilan terhadap tenaga kerja asing di Indonesia. Berdasarkan tulisan ini, tenaga kerja asing merupakan salah satu subyek pajak penghasilan di Indonesia dan dapat menjadi subyek pajak dalam negeri atau subyek pajak luar negeri tergantung dari berapa lama berada di Indonesia, karena mendapatkan penghasilan atas apa yang dikerjakan di Indonesia. Sedangkan apabila terjadi suatu penyelewengan berkaitan dengan pajak penghasilan terhadap tenaga kerja asing dalam hal ini pemotongan pajaknya dilakukan oleh perusahaan tempat tenaga kerja asing tersebut bekerja, maka yang mendapatkan sanksi atas terjadinya penyelewengan adalah pihak yang memotong pajak penghasilan tersebut.
\end{abstract}

Kata Kunci: Tenaga Kerja Asing; Pajak Penghasilan; Subyek Hukum.

\section{Pendahuluan}

Sebagai negara kepulauan terbesar di dunia dan memiliki posisi yang strategis maka peluang negara Indonesia dalam meningkatkan pendapatan dan penerimaan negara sangat besar melalui berbagai sektor, salah satunya adalah melalui pajak. Dewasa ini tidak dapat dipungkiri lagi bahwa untuk mewujudkan kemandirian 
dalam pembiayaan pembangunan sangat bergantung kepada penerimaan yang ada di dalam negeri yang dapat bersumber dari pajak yang ada di negara ini, banyakya sektor-sektor yang dapat dijadikan sebagai sumber pajak merupakan peluang bagi pemerintah untuk memperoleh manfaat dari hal tersebut sebagai pendongkrak Anggaran Pendapatan Belanja Negara (APBN), untuk mendukung dan mengumpulkan hasil dari sektor pajak tersebut yang setiap tahun semakin meningkat jumlahnya tentu bukan hal yang mudah, sehigga diperlukan suatu kesadaran yang tinggi baik oleh masyarakat wajib pajak dalam melaksanakan kewajiban perpajakannya dengan didukung oleh aparatur perpajakan yang tangguh serta sistem administrasi perpajakan yang memadai disamping juga adanya piranti hukum yang memberikan rasa keadilan serta kepastian hukum.

Dalam pengaturan Pasal 23 A UUD NRI Tahun 1945 Pajak dan pungutan lain yang bersifat memaksa untuk keperluan negara diatur dengan undang-undang, sejalan dengan aturan tersebut maka dalam rangka pemungutan pajak wajib adanya aturan perundang-undangan yang mendasarinya demi menjamin kepastian hukum. Tujuan hukum adalah untuk menciptakan damai sejahtera dalam hidup bermasyarakat. ${ }^{1}$ Dalam mencapai tujuannya tersebut hukum bertugas membagi hak dan kewajiban antar perorangan di dalam masyarakat, membagi wewenang dan mengatur cara memecahkan masalah hukum serta memelihara kepastian hukum.

Fungsi pajak sebagai salah satu unsur terpenting dalam menopang keberlangsungan suatu negara sangatlah penting dan sentral, di Indonesia sendiri pajak berperan sebagai salah satu penerimaan negara, karena itu pemerintah sampai saat ini terus berupaya menggali potensi yang dapat diberlakukan pajak (tax coverage) dan berupaya dalam rangka meningkatkan kepatuhan masyarakat (tax compliance). Penghasilan negara adalah berasal dari rakyatnya melalui pungutan pajak dan dari hasil kekayaan alam yang ada di dalam negara itu. Dua sumber itu merupakan sumber terpenting yang memberikan penghasilan kepada negara. Penghasilan itu untuk membiayai kepentingan umum yang akhirnya juga

${ }^{1}$ Peter Mahmud Marzuki, Pengantar Ilmu Hukum (Kencana Prenada Media Group 2009).[162]. 
mencakup kepentingan pribadi, seperti kesehatan rakyat, pendidikan, kesejahteraan dan sebagainya. Jadi, dimana ada kepentingan masyarakat disana timbul pungutan pajak sehingga pajak adalah senyawa dengan kepentingan umum. ${ }^{2}$

Bidang industri merupakan bisnis yang paling banyak menyerap tenaga kerja di Indonesia. Dalam kegiatan bisnis sendiri tenaga kerja sebagai unsur utama dalam pelaksanaan kegiatan bisnis itu sendiri. Berdasarkan Pasal 1 angka (2) UndangUndang Nomor 13 Tahun 2003 Tentang Ketenagakerjaan (Selanjutnya disebut UU No. 13/2003) yang dimaksud sebagai tenaga kerja adalah setiap orang yang mampu melakukan pekerjaan guna menghasilkan barang dan/atau jasa baik untuk memenuhi kebutuhan sendiri maupun untuk masyarakat. Di Indonesia sendiri tidak hanya menggunakan tenaga kerja yang berasal dari Indonesia saja, melainkan juga menggunakan tenaga kerja asing. Berdasarkan pengaturan Pasal 1 angka 13 UU No. 13/2003, tenaga kerja asing adalah warga negara asing pemegang visa dengan maksud bekerja di wilayah Indonesia.

Sebagai tenaga kerja asing yang bekerja di Indonesia secara langsung hak dan kewajiban yang dimiliki diatur sesuai dengan peraturan perundang-undangan yang berlaku di Indonesia, termasuk juga aturan yang berkaitan dengan perpajakan. Tidak jarang masalah hukum dibidang perpajakan muncul, baik itu yang bersumber dari wajib pajak, maupun dari sisi fiskus. Bagi sebagian masyarakat menjadi seorang wajib pajak justru dianggap sebagai hal yang merugikan, sebab dengan adanya penarikan pajak dari pemerintah disisi lain dianggap mengurangi pendapatan yang diperoleh oleh seorang wajib pajak padahal tujuan dari penarikan pajak bukan untuk mengurangi pendapatan dari seorang wajib pajak, melainkan bertujuan untuk mengisi kas negara yang nantinya digunakan juga untuk mensejahterakan masyarakat.

Terhadap tenaga kerja asing tersebut berhak atas standar upah penghasilan yang sesuai dengan kewajaran dan kepatutan yang ada di Indonesia. Tenaga kerja asing yang berada di Indonesia dapat menjadi subyek hukum pajak di Indonesia,

\footnotetext{
2009).[2].

${ }^{2}$ Deddy Sutrisno dan Indrawati, Bahan Ajar Mata Kuliah Hukum Pajak(Univesitas Airlangga
} 
sehingga hak dan kewajibannya dibidang perpajakan berlaku, oleh karena itu demi terciptanya ketertiban hukum dibidang perpajakan perlu adanya upaya penerapan hukum pajak penghasilan terhadap tenaga kerja asing.

\section{Dasar Hukum Pengenaan Pajak Penghasilan Tenaga Kerja Asing di Indonesia}

\section{A. Penggunaan Tenaga Kerja Asing}

Penggunaan tenaga kerja asing di Indonesia dilakukan antara lain untuk mencari nilai tambah atau manfaat positif dengan adanya tenaga kerja asing tersebut sebagai alih teknologi dan memicu daya saing bagi tenaga kerja lokal. Penggunaan tenaga kerja asing di Indonesia diawasi oleh Pemerintah antara lain dengan menggunakan regulasi-regulasi, yang berfungsi sebagai sarana pengaturan, pengendalian dan pengawasan bagi pihak-pihak yang menggunakan tenaga kerja asing, dan menjamin adanya suatu kepastian hukum.

Dalam Pasal 1 angka 13 UU No. 13/2003 yang dimaksud tenaga kerja asing adalah warga negara asing pemegang visa dengan maksud bekerja di wilayah Indonesia. Pengertian tenaga kerja asing dalam UU No. 13/2003 tersebut mensyaratkan wajib bagi warga negara asing memiliki visa untuk bekerja di Indonesia. Dalam pengaturan Pasal 1 angka 18 UU Nomor 6 Tahun 2011 Tentang Keimigrasian yang dimaksud dengan visa adalah keterangan tertulis yang diberikan oleh pejabat yang berwenang di Perwakilan Republik Indonesia yang memuat persetujuan bagi orang asing untuk melakukan perjalanan ke wilayah Indonesia dan menjadi dasar untuk pemberian izin tinggal.

Hukum ketenagakerjaan di Indonesia berkaitan dengan penggunaan tenaga kerja asing wajib untuk memiliki izin tertulis dari pejabat yang berwenang, izin tersebut adalah IMTA (Izin Memperkerjakan Tenaga Kerja Asing). IMTA tersebut wajib dimiliki bagi setiap Pemberi Kerja yang memperkerjakan Tenaga Kerja Asing di Indonesia. Fungsi izin sebagai suatu perbuatan hukum administrasi yang bersegi satu yang diaplikasikan dalam suatu peraturan berdasarkan persyaratan-persyaratan dan prosedur sebagaimana ketentuan peraturan perundang-undangan. 
Dalam hal mendatangkan tenaga keraja asing maka harus diikat dengan suatu perjanjian kerja yang mengakibatkan suatu hubungan kerja, yaitu hubungan kerja antara buruh dan majikan terjadi setelah diadakan perjanjian oleh buruh dan majikan, dimana buruh menyatakan kesanggupannya untuk bekerja pada majikan dengan menerima upah dan majikan menyatakan kesanggupannya untuk memperkerjakan buruh dengan membayar upah. ${ }^{3}$

Pemerintah juga mengatur berkaitan dengan jabatan-jabatan tertentu yang tidak boleh diisi atau diduduki oleh tenaga kerja asing melalui Keputusan Menakertrans Nomor 40 Tahun 2012 Tentang Jabatan-Jabatan Tertentu Yang Dilarang Diduduki Tenaga Kerja Asing, terdapat 19 jabatan yang dilarang diduduki oleh tenaga kerja asing. Dalam penggunaan tenaga kerja asing oleh pemberi kerja lebih lanjut diatur dalam Peraturan Menteri Tenaga Kerja Dan Transmigrasi Republik Indonesia Nomor 16 Tahun 2015 Tentang Tata Cara Penggunaan Tenaga Kerja Asing.

Dalam Pasal 42 ayat 2 UU No. 13/2003 diatur jika Pemberi Kerja orang perorangan dilarang untuk memperkerjakan tenaga kerja asing. Sebelum memperoleh IMTA, pemberi kerja yang akan memperkerjakan tenaga kerja asing wajib memiliki Rencana Penggunaan Tenaga Kerja Asing (RPTKA), RPTKA adalah rencana penggunaan tenaga kerja asing pada jabatan tertentu yang dibuat oleh pemberi kerja TKA untuk jangka waktu tertentu yang disahkan oleh Menteri atau pejabat yang ditunjuk, RPTKA ini adalah dasar diterbitkannya IMTA.

\section{B. Pemungutan Pajak Penghasilan Terhadap Tenaga Kerja Asing}

Terhadap tenaga kerja asing yang bekerja di Indonesia merupakan Subyek pajak penghasilan yang ada di Indonesia, dalam pengaturan UU Nomor 36 Tahun 2008 Tentang Pajak Penghasilan (selanjutnya disebut UU No. 36/2008). Subyek pajak dibagi menjadi subyek pajak dalam negeri dan subyek pajak luar negeri. Perbedaan tersebut berdasarkan kriteria yang diatur dalam Pasal 2 UU No. 36/2008. Tenaga kerja asing yang berkerja di Indonesia dapat menjadi Subyek Pajak Dalam

${ }^{3}$ Lanny Ramli, Hukum Ketenagakerjaan (Airlangga University 2008).[23]. 
Negeri dan dapat pula menjadi Subyek Pajak Luar Negeri, hal tersebut tergantung apakah warga negara asing tersebut berada di Indonesia lebih dari 183 hari dalam 12 bulan, atau tidak lebih dari 183 hari dalam 12 bulan.

Tenaga kerja asing yang bekerja di Indonesia lebih dari 183 hari dalam 12 bulan maka dapat menjadi subyek pajak dalam negeri. Ketika menjadi subyek pajak dalam negeri maka tenaga kerja asing tersebut wajib memiliki Nomor Pokok Wajib Pajak (NPWP), dalam pengaturan Pasal 1 angka 6 UU Nomor 28 Tahun 2007 Tentang Ketentuan Umum dan Tata Cara Perpajakan (Selanjutnya disebut UU No. 28/2007) yang dimaksud NPWP adalah nomor yang diberikan kepada Wajib Pajak sebagai sarana dalam administrasi perpajakan yang dipergunakan sebagai tanda pengenal diri atau identitas Wajib Pajak dalam melaksanakan ha dan kewajiban perpajaknnya. Fungsi NPWP yaitu: ${ }^{4}$

1. Sarana dalam administrasi perpajakan;

2. Tanda pengenal diri atau identitas wajib pajak dalam melaksanakan;

3. Dicantumkan dalam setiap dokumen perpajakan;

4. Menjaga ketertiban dalam pembayaran pajak dan pengawasan administrasi perpajakan.

NPWP wajib dimiliki bagi semua Wajib Pajak yang telah memenuhi persyaratan subyektif dan obyektif sesuai dengan ketentuan peraturan perundang- undangan. Persyaratan subyektif yaitu persyaratan sesuai dengan ketentuan UU No. 36/2008, sedangkan persyaratan obyektif yaitu persyaratan bagi subyek pajak yang menerima atau memperoleh penghasilan atau diwajibkan untuk melakukan pemotongan atau pemungutan sesuai dengan undang-undang pajak penghasilan. Bagi wajib pajak yang tidak mendaftarkan diri untuk mendapatkan NPWP dapat dikenai sanksi sesuai dengan ketentuan peraturan perpajakan, sebagaimana diatur dalam Pasal 39 UU No. 28/2007, sanksi yang diberikan adalah sanksi pidana penjara dan denda.

Tenaga kerja asing dapat menjadi subyek pajak luar negeri adalah orang pibadi yang tidak lebih dari 183 hari dalam 12 bulan berada di Indonesia sehubungan dengan penghasilan yang diterima dari sumber penghasilan di Indonesia bukan dari

${ }^{4}$ Aristanti Widyaningsih, Hukum Pajak Dan Perpajakan Dengan Pendekatan MindMap (Alfabeta 2011).[229]. 
menjalankan usaha atau melakukan kegiatan melalui BUT di Indonesia namun dari penghasilan dalam suatu hubungan kerja dengan perusahaan Indonesia.

Secara umum dasar pengenaan pajak adalah nilai berupa uang yang dijadikan dasar untuk menghitung pajak yang terutang. Untuk wajib pajak dalam negeri yang menjadi dasar pengenaan pajaknya adalah penghasilan kena pajak, sedangkan untuk wajib pajak luar negeri adalah penghasilan bruto. ${ }^{5}$ Terhadap pemotongan pajak penghasilan tenaga kerja asing baik itu sebagaimana pengaturan Pasal 21 atau Pasal 26 UU No. 36/2008 dilakukan oleh pemberi kerja yang membayar gaji, upah, honorarium, dan pembayaran lain dengan nama apapun sebagai imbalan sehubungan dengan pekerjaan atau jasa yang dilakukan oleh Wajib Pajak sebagai pekerja yang dipekerjakan dalam perusahaan tersebut.

\section{Bentuk Pertanggung Jawaban Bagi Pelanggar Pengaturan Pajak Penghasilan Terhadap Tenaga Kerja Asing di Indonesia}

\section{A. Sanksi Bagi Pelanggar Pengaturan Pajak Penghasilan Terhadap Tenaga Kerja Asing.}

Penegakan hukum dibidang perpajakan merupakan hal yang wajib dilakukan oleh Pemerintah melalui pejabat yang diberikan untuk melaksanakan penegakan hukum. Penegakan hukum ini dilakukan berkaitan dengan adanya suatu pelanggaran atas suatu ketentuan hukum yang ada. Pelanggaran yang terjadi tersebut dapat terjadi melalui suatu perlawanan pajak. Adapun definisi perlawanan pajak adalah hambatan-hambatan baik yang disebabkan oleh kondisi negara dan rakyatnya maupun disebabkan oleh usaha-usaha wajib pajak yang disadari maupun tidak, yang mempersulit pemasukan pajak sebagai sumber penerimaan negara. ${ }^{6}$

Sanksi adalah suatu bentuk imbalan atau balasan atas perilaku yang dilakukan, sanksi diterapkan di masyarakat sebagai menjaga tingkah laku agar sesuai dengan norma-norma yang ada. Sanksi perpajakan adalah sanksi berupa administrasi

\footnotetext{
${ }^{5}$ ibid.[29].

${ }^{6}$ Sumyar, Dasar-Dasar Hukum Pajak Dan Perpajakan (Andi Ofset 2014).[39].
} 
dan pidana yang dikenakan terhadap setiap orang yang melakukan pelanggaran perpajakan yang secara nyata telah diatur dalam Undang-undang. ${ }^{7}$

Sanksi perpajakan adalah jaminan bahwa ketentuan peraturan perundangundangan perpajakan (norma perpajakan) akan dituruti/ditaati/dipatuhi atau dengan kata lain sanksi perpajakan merupakan alat pencegah (preventif) agar wajib pajak tidak melanggar norma perpajakan. ${ }^{8}$ Dari pernyataan tersebut maka sanksi dalam perpajakan dapat dibagi menadi dua yaitu sanksi administrasi dan sanksi pidana.

Pengertian sanksi administrasi menurut Siti Resmi merupakan pembayaran kepada negara, khususnya yang berupa bunga dan kenaikan. Sanksi administrasi dapat dibedakan menjadi tiga: ${ }^{9}$

a. Denda adalah sanksi administrasi yang dikenakan terhadap pelanggaran yang berkaitan dengan kewajiban pelaporan;

b. Bunga adalah sanksi administrasi yang dikenakan terhadap pelanggaran yang berkaitan dengan kewajiban pembayaran pajak;

c. Kenaikan yang harus dibayar, terhadap pelanggaran berkaitan dengan kewajiban yang diatur dalam ketentuan material.

Sanksi administrasi merupakan pembayaran kerugian kepada Negara, khususnya berupa bunga dan kenaikan. ${ }^{10}$ Sanksi administrasi yang diatur dalam KUP dibagi menjadi tiga jenis yaitu denda, bunga, dan kenaikan. Sanksi administrasi tersebut diberikan berkaitan dengan adanya pelanggaran norma hukum publik. Sanksi administrasi berupa bunga sebesar 25\% sebulan diberikan terhadap wajib pajak yang membetulkan SPT, dikenakan SKPKB (Surat Ketetapan Pajak Kurang Bayar), tidak melunasi utang pajak pada saat jatuh tempo, terlambat membayar SKPKB dan SKPKBT, mengangsur atau menunda pembayaran pajak serta menunda penyimpanan SPT, sedangkan untuk sanksi administrasi berupa kenaikan adalah merupakan sanksi berupa kenaikan jumlah pajak yang harus

\footnotetext{
${ }^{7}$ Widyaningsih.Op.Cit.[312].

${ }^{8}$ Mardiasmo, Perpajakan (Andi Ofset 2001).[146].

${ }^{9}$ Rahayu Sony Devano dan Siti Kurnia, Perpajakan: Konsep, Teori, Dan Isu (Kencana Prenada Media Group 2006).[198].

${ }^{10}$ Erly Suandy, Hukum Pajak Edisi 4 (Salemba Empat 2008).[155].
} 
dibayar wajib pajak dengan presentase antara 50-100\% dari jumlah pajak yang tidak/kurang dibayar.

Sanksi pidana merupakan suatu alat terakhir atau benteng hukum yang digunakan fiskus agar norma perpajakan dipatuhi. ${ }^{11}$ Sanksi pidana yang diatur dalam undang-undang perpajakan dapat berupa denda pidana, denda kurungan maupun pidana penjara. Adapun penjelasan macam sanksi pidana sebagai berikut: ${ }^{12}$

a. Denda pidana, berbeda dengan sanksi berupa denda administrasi yang hanya diancam/dikenakan kepada Wajib Pajak ada juga yang diancamkan kepada pejabat pajak atau kepada pihak ketiga yang melanggar norma. Denda pidana dikenakan kepada tindak pidana yang bersifat pelanggaran maupun bersifat kejahatan.

b. Pidana kurungan hanya dapat diancamkan kepada tindak pidana yang bersifat pelanggaran. Dapat ditujukan kepada Wajib Pajak, dan pihak ketiga.

c. Pidana penjara, Pidana penjara seperti halnya pidana kurungan, merupakan hukuman perampasan kemerdekaan. Pidana penjara diancamkan terhadap kejahatan. Ancaman pidana penjara tidak ada yang ditujukan kepada pihak ketiga, adanya kepada pejabat dan kepada Wajib Pajak.

Tiada gunanya memberlakukan kaidah-kaidah hukum manakala kaidahkaidah itu tidak dapat dipaksakan melalui sanksi dan menegakkan kaidah-kaidah dimaksud secara prosedural (hukum acara). Salah satu upaya pemaksaan hukum (law enforcement) itu adalah melalui pemberlakuan sanksi pidana terhadap pihak pelanggar mengingat sanksi pidana membawa serta akibat hukum yang berpaut dengan kemerdekaan pribadi (berupa pidana penjara, kurungan, dan denda) dari pelanggar yang bersangkutan. Itulah sebabnya, hampir pada berbagai ketentuan kaidah perundang-undangan (termasuk utamanya di bidang pemerintahan dan pembangunan negara) selalu disertai dengan pemberlakuan sanksi pidana, berupa pidana penjara, kurungan, denda dan semacamnya. ${ }^{13}$

\footnotetext{
${ }^{11}$ ibid.

${ }^{12}$ Siti Resmi, Perpajakan: Teori Dan Kasus Buku Satu (Salemba Empat 2003).[63].

${ }^{13}$ M Hadjon et al Philipus, Pengantar Hukum Administrasi Indonesia (Gadjah Mada University Press 2002).[672].
} 
Pidana penjara pada dasarnya untuk menimbulkan rasa derita pada terpidana karena hilagnya kemerdekaan bergerak, membimbing terpidana agar bertobat, mendidik dan mengarahkan kepada kegiatan yang positif, selain itu tujuannya adalah pembinaan bagi terpidana. Pemotong PPh Pasal 21 dan/atau PPh Pasal 26 adalah wajib pajak orang pribadi atau wajib pajak badan, termasuk bentuk usaha tetap, yang mempunyai kewajiban untuk melakukan pemotongan pajak atas penghasilan sehubungan dengan pekerjaan, jasa dan kegiatan orang pribadi sebagaimana dimaksud dalam Pasal 21 dan Pasal 26 UU No. 36/2008. Dalam pengaturan Pasal 1 angka 4 Peraturan Direktur Jenderal Pajak Nomor: Per-16/ PJ/2016 Tentang Pedoman Teknis Tata Cara Pemotongan, Penyetoran dan Pelaporan Pajak Penghasilan Pasal 21 dan/atau Pajak Penghasilan Pasal 26 Sehubungan Dengan Pekerjaan, Jasa, dan Kegiatan Orang Pribadi. Pengaturan Pasal 21 UU No. 36/2008 juga dijelaskan jika pemotong pajak adalah pemberi kerja baik orang perorangan, maupun berbentuk badan hukum, namun untuk memperkerjakan tenaga kerja asing tidak boleh dilakukan oleh orang perorangan, sehingga apabila terjadi penyelewengan dalam pembayaran pajak penghasilan terhadap tenaga kerja asing maka yang bertanggungjawab adalah pemotong dari pajak penghasilan tenaga kerja asing tersebut yaitu adalah perusahaannya, sehingga pada dasarnya penerapan sanksi berkaitan dengan pajak penghasilan bagi tenaga kerja asing baik itu sanksi administrasi atau pidana diterapkan terhadap pihak pemotong penghasilan tenaga kerja asing tersebut, karena pihak tersebut yang melaksanakan pembayaran atas upah yang diperoleh tenaga kerja asing, baik itu tenaga kerja asing yang berstatus sebagai subyek pajak dalam negeri, maupun tenaga kerja asing yang berstatus sebagai subyek pajak luar negeri.

\section{B. Penegakan hukum pajak penghasilan}

Penegakan hukum hakikatnya merupakan upaya menyelaraskan nilai-nilai hukum dengan merefleksikan di dalam bersikap dan bertindak di dalam bersikap dan bertindak di dalam pergaulan demi terwujudnya keadilan, kepastian hukum dan kemanfaatan dengan menerapkan sanksi-sanksi bagi pelanggar aturan 
hukum yang ada. Penegakan hukum dalam bidang perpajakan bertujuan untuk menciptakan kepatuhan kepada wajib pajak oleh fiskus. Berdasarkan Keputusan Menteri Keuangan No. 544/KMK.04/2000 Kepatuhan perpajakan adalah tindakan Wajib Pajak dalam pemenuhan kewajiban perpajakannya sesuai dengan ketentuan peraturan perundang-undangan dan peraturan pelaksanaan perpajakan yang berlaku dalam suatu Negara. Menurut Safri Nurmantu, kepatuhan wajib pajak didefinisikan sebagai suatu keadaan dimana wajib pajak dapat memenuhi semua kewajiban perpajakan dan melaksanakan hak perpajakannya. Terdapat dua macam kepatuhan perpajakan, yaitu kepatuhan formal dan kepatuhan material. ${ }^{14}$

Dalam Penegakan hukum ada tiga unsur yang harus diperhatikan, yaitu unsur kepastian hukum, kemanfaatan, dan keadilan. Dengan adanya kepastian hukum masyarakat akan lebih tertib, masyarakat juga mengharapkan manfaat yang dapat diperoleh dari ditegakkannya hukum itu. Dalam pelaksanaan penegakan hukum itu masyarakat mengharapkan juga agar hukum bisa memberikan keadilan bagi kepentingan mereka. Pada hakikatnya, dalam penegakan hukum harus ada kompromi antara ketiga unsur tersebut. Ketiganya harus mendapat perhatian yang proporsional seimbang walaupun dalam prakteknya tidak selalu mudah mengusahakan kompromi secara proporsional seimbang antara ketiganya tersebut. ${ }^{15}$

Penegakan hukum dibidang perpajakan dapat dilakukan dengan 3 (tiga) tahapan yaitu, penagihan, pemeriksaan, dan penyidikan. Dalam pengaturan Pasal 1 angka 25 UU No. 19 Tahun 2000 Penagihan Pajak adalah serangkaian tindakan agar Penanggung Pajak melunasi utang pajak dan biaya penagihan pajak dengan menegur atau memperingatkan, melaksanakan penagihan seketika dan sekaligus, memberitahukan Surat Paksa, mengusulkan pencegahan, melaksanakan penyitaan, melaksanakan penyanderaan, menjual barang yang telah disita. Yang dimaksud sebagai penagihan dengan seketika dan sekaligus adalah penagihan yang dilakukan oleh Jurusita Pajak kepada Penanggung Pajak tanpa menunggu

\footnotetext{
${ }^{14}$ Safri Nurmantu, Pengantar Perpajakan (Kelompok Yayasan Obor ed, 2003).[148].

${ }^{15}$ Sudikno Mertokusumo, Mengenal Hukum Suatu Pengantar (Liberty 2008).[161].
} 
tanggal jatuh tempo pembayaran yang meliputi seluruh utang pajak dari semua jenis pajak, masa pajak, dan tahun pajak. Dalam penagihan perpajakan pada dasarnya dibagi menjadi dua jenis, yaitu penagihan yang bersifat pasif dan bersifat aktif. Penagihan yang bersifat pasif seperti: ${ }^{16}$

a. Dengan cara memberi peringatan;

b. Setelah itu memberi terguran;

c. Disusul dengan aturan pencicilan pembayaran atau tidak.

Prosedur lain selain penagihan untuk mewujudkan kepatuhan perpajakan oleh wajib pajak yang dapat dilakukan oleh Fiskus adalah dengan melakukan Pemeriksaan. Berdasarkan Peraturan Direktur Jenderal Pajak Nomor KEP-142/ PJ/2005 Tentang Petunjuk Pelaksanaan Pemeriksaan Kantor, yang dimaksud Pemerikasaan adalah serangkaian kegiatan untuk mencari, mengumpulkan, mengolah data dan atau keterangan lainnya untuk menguji kepatuhan pemenuhan kewajiban perpajakan dan untuk tujuan lain dalam rangka melaksanakan ketentuan peraturan perundang-undangan perpajakan.

Langkah selain melaksanakan penagihan dan pemeriksaan untuk mewujudkan kepatuhan perpajakan adalah Penyidikan Pajak. Penyidikan tersebut dilakukan beraitan adanya dugaan tindak pidana yang berkaitan dengan perpajakan, hukum perpajakan sendiri merupakan hukum publik, oleh sebab itu negara melalui aparatur pelaksananya berhak melaksanakan upaya penegakan hukum, selain itu juga dalam hukum perpajakan sendiri tidak hanya berakaitan dengan hukum administrasi tapi juga berkaitan dengan hukum pidana, oleh sebab itu dapat dilakukan upaya penyidikan dalam hukum perpajakan.

Dalam pengaturan Pasal 1 angka 31 KUP Penyidikan pajak adalah serangkaian tindakan yang dilakukan oleh penyidik untuk mencari serta mengumpulkan bukti, yang dengan bukti itu membuat terang tindak pidana dibidang perpajakan yang terjadi serta menemukan tersangkanya. Berdasarkan pengaturan Pasal 44 ayat 1 KUP Penyidikan tindak pidana di bidang perpajakan hanya dapat dilakukan oleh

\footnotetext{
${ }^{16}$ Santoso Brotodiharjo, Pengantar Ilmu Hukum Pajak (Refika Aditama 2001).[13].
} 
Pejabat Pegawai Negeri Sipil tertentu di lingkungan Direktorat Jenderal Pajak yang diberi wewenang khusus sebagai penyidik tindak pidana dibidang perpajakan, sedangkan prosedur formalnya untuk melaksanakan penyidikan tindak pidana perpajakan tetap mengacu pada KUHAP.

Berdasarkan pengaturan Pasal 1 angka 5 Peraturan Pemerintah No 43 Tahun 2012 Tentang Tata Cara Pelaksanaan Koordinasi, Pengawasan, Dan Pembinaan Teknis Terhadap Kepolisian Khusus, Penyidik Pegawai Negeri Sipil, Dan BentukBentuk Pengamanan wakarsa, Pejabat Pegawai Negeri Sipil (PPNS) adalah Pengangkatan pegawai negeri sipil selaku petugas penyidik (PPNS) menurut ketentuan Pasal 6 ayat 1 butir b Kitab Undang-Undang Hukum Acara Pidana (KUHAP) sangat memungkinkan efektivitas pemberlakuan dan penegakan sanksi pidana dari kaidah hukum tertentu yang sifatnya lebih "bestuur burger rechlijk", seperti halnya kaidah-kaidah hukum berkenaan dengan lingkungan hidup, kawasan hutan, industri perdagangan, perlindungan hak cipta/hak merk dan masalah-masalah penertiban perkotaan. Namun dalam kenyataan, masih terdapat adanya kaidah-kaidah hukum tertentu, seperti halnya peraturan-peraturan daerah, yang belum diketahui secara meluas di kalangan para warga, sedangkan kaidahkaidah hukum tersebut diberlakukan pada mereka. ${ }^{17}$

Menurut Djoko Slamet dan Junaedi Eko Wibowo pada hakikatnya kepatuhan Wajib Pajak dipengaruhi oleh kondisi system pelayanaan (tax service) dan sistem penegakan hukum (tax enforcement). Langkah-langkah perbaikan pelayanan dan penegakan hukum diharapkan dapat mendorong meningkatnya kepatuhan Wajib Pajak untuk secara sukarela memenuhi seluruh kewajiban perpajakanya. Disisi lain, penegakan hukum (tax enforcement) yang berwibawa akan membuat Wajib Pajak berfikir bahwa mereka akan mendapat sanksi yang berat jika pajak yang tidak mereka laporkan terdeteksi oleh sistem informasi dan adminisitrasi perpajakan serta kemampuan untuk crosschejing informasi dan instansi lain.

${ }^{17}$ Philipus. Op.Cit.[763]. 


\section{Kesimpulan}

Tenaga kerja asing merupakan salah satu subyek pajak penghasilan di Indonesia dan dapat menjadi subyek pajak dalam negeri atau subyek pajak luar negeri tergantung dari berapa lama berada di Indonesia, karena mendapatkan penghasilan atas apa yang dikerjakan di Indonesia. Penarikan pajak penghasilan terhadap tenaga kerja asing dibebankan kepada perusahaan/badan tempat Tenaga Kerja Asing tersebut bekerja dan mendapatkan penghasilan.

Apabila terjadi suatu penyelewengan berkaitan dengan pajak penghasilan terhadap tenaga kerja asing dalam hal ini pemotongan pajaknya dilakukan oleh perusahaan tempat tenaga kerja asing tersebut bekerja, maka yang mendapatkan sanksi atas terjadinya penyelewengan adalah pihak yang memotong pajak penghasilan tersebut. Bentuk sanksi yang diberikan dapat berupa sanksi administrasi yaitu berupa denda, bunga, dan kenaikan yang harus dibayar, selain sanksi administrasi dapat juga diberikan sanksi pidana berupa pidana penjara, kurungan, dan denda.

\section{Daftar Bacaan}

\section{Buku}

Aristanti Widyaningsih, Hukum Pajak Dan Perpajakan Dengan Pendekatan MindMap (Alfabeta 2011).

Deddy Sutrisno dan Indrawati, Bahan Ajar Mata Kuliah Hukum Pajak (Univesitas Airlangga 2009).

Erly Suandy, Hukum Pajak Edisi 4 (Salemba Empat 2008).

Lanny Ramli, Hukum Ketenagakerjaan (Airlangga University 2008).

Mardiasmo, Perpajakan (Andi Ofset 1996).

M Hadjon et al Philipus, Pengantar Hukum Administrasi Indonesia (Gadjah Mada University Press 2002).

Peter Mahmud Marzuki, Pengantar Ilmu Hukum (Kencana Prenada Media Group 2009).

Rahayu Sony Devano dan Siti Kurnia, Perpajakan: Konsep, Teori, Dan Isu 
(Kencana Prenada Media Group 2006).

Safri Nurmantu, Pengantar Perpajakan (Kelompok Yayasan Obor ed, 2003).

Santoso Brotodiharjo, Pengantar Ilmu Hukum Pajak (Refika Aditama 2010).

Siti Resmi, Perpajakan: Teori Dan Kasus Buku Satu (Salemba Empat 2003).

Sudikno Mertokusumo, Mengenal Hukum Suatu Pengantar (Liberty 2008).

Sumyar, Dasar-Dasar Hukum Pajak Dan Perpajakan (Andi Ofset 2004).

HOW TO CITE: Hendy Ramadhan, 'Pajak Penghasilan Terhadap Tenaga Kerja Asing Sebagai Subyek Hukum Pajak' (2018) Vol 1 No 2

Media Iuris. 